\title{
MANAGING BIOLOGICAL SUCCESSION IN INTENSIVE PASTORAL ECOSYSTEMS FOR IMPROVED PRODUCTION AND SUSTAINABILITY
}

\author{
N.L. BELL, S. HARDWICK, J.P.J EERENS and T.K. JAMES \\ AgResearch, Private Bag 3123, Hamilton, New Zealand \\ Corresponding author: nigel.bell@agresearch.co.nz.
}

\begin{abstract}
Use of forage succession to increase productivity and upgrade run-out pasture has become an integral part of modern pastoral production systems. Use of new forage types has increased along with increases in area sown. This growth in forage crop use and diversity has largely been without a co-ordinated view to long term benefits and costs in terms of weeds, pests and diseases. This paper describes the potential impacts on insects, weeds and nematodes of a forage succession (pasture to turnips to annual ryegrass to turnips to perennial ryegrass/white clover) that commonly occurs in the Waikato region of New Zealand. Pest distributions, host ranges, phenology and survival biology are used to elucidate strengths and weaknesses of the rotation. Knowledge gaps are identified so that they can be addressed and add to robust forage succession design in the future.
\end{abstract}

Keywords: pasture, forage crop, weed, pest, nematode.

\section{INTRODUCTION}

Pastoral production systems are becoming increasingly intensive and in recent times have taken on the appearance of a mixed farming operation in which forage cropping can now take up to $30 \%$ of the available land area. The economic risk associated with high input systems is that they often operate on a narrow profitability ledge and it does not take a major disaster for the system to return an unfavourable result in spite of best efforts. Forage diversification is likely to improve economic and environmental buffering, although from a farmer's point of view, consistent high yields are expected from all components.

Where pastures have become weakened by pests and weeds, a forage succession is used to break pest and weed cycles between consecutive grass phases, often in conjunction with pesticide use. The causes of the pasture decline (run-out) can include direct pest damage, weed ingress or a combination of pest damage weakening pasture growth, causing pasture cover to diminish and thereby allowing weed ingress. If the causes of the pasture decline are identified on a farm or even to a region level it is possible to devise a succession to break weed (Wardle et al. 1995) and pest cycles so subsequent pasture that is established is much more productive than the run-out state (Goold \& Weeda 1985) and will remain so for a number of years. In addition, new cultivars can be established after a succession, which ensures the full benefit of their traits (Bluett et al. 2004). Therefore, managing as many as possible of the biological components of the forage succession will likely maximise productivity and longevity of re-established pastures and so farmers' economic return.

Most, if not all, of the forage successions currently in use have been driven by the farming community, with little research to evaluate the long-term impact of the succession on pests and diseases. While there is considerable information available on the short-term impact of forage succession, the forage system has become increasingly complex with an increasing number of forage species being used and for longer periods of time. The combined impacts of these changes on soil biota have not been evaluated. Component 
research is still appropriate but there is a need to combine components in the move to whole farm research.

This paper provides a theoretical assessment of the likely impact on pasture pests (especially soil-dwelling), weeds and nematodes of a common forage succession used in Waikato dairy farms. The assessment is based on a combination of literature review and unpublished data. The forage succession involves permanent pasture (mainly perennial ryegrass (Lolium perenne) and white clover (Trifolium repens)) to turnips (Brassica rapa L var rapa) to Italian/short rotation ryegrass (Lolium multiflorum) to turnips to permanent pasture. Three successional stages are considered, run-out pasture, forage crops and re-established pasture, and each stage of the succession is accompanied by cultivation. The aim is to examine the often contrasting effects that a specific rotation may have on different pest classes as a basis for more detailed research in the future.

\section{RUN-OUT PASTURE}

A wide range of insect pests occur in New Zealand pastures. In this analysis grass grub (Costelytra zealandica), Argentine stem weevil (Listronotus bonariensis), black beetle (Heteronychus arator), clover root weevil (Sitona lepidus), porina (Wiseana spp.) and Tasmanian grass grub (Acrossidius tasmaniae) are considered to be associated with run-out pasture. Of these insect pests, clover root weevil, Argentine stem weevil and grass grub are potentially the most widespread and important in New Zealand pastoral systems (Eerens et al. 2005; Goldson et al. 2005). Currently, clover root weevil is found in pastures throughout the North Island and its presence has been confirmed in the Nelson and Canterbury regions of the South Island (Eerens et al. 2005; C.B. Phillips, pers. comm.). Argentine stem weevil and grass grub are found throughout New Zealand although grass grub generally does not reach pest status in Northland (Chapman 1984). Tasmanian grass grub and porina distribution and pest status vary both between and within regions (East et al. 1981; Blank 1985; Barratt et al. 1990), while black beetle is limited to areas with an average annual temperature of ca $12^{\circ} \mathrm{C}$ (Watson 1980).

In pastoral systems clover root weevil feeds exclusively on plants in the genus Trifolium showing a strong preference for white clover (T. repens) (Clements \& Murray 1991), while Argentine stem weevil and black beetle are pests of graminaceous plants (King et al. 1982; Barker et al. 1999). Grass grub, Tasmanian grass grub and porina will feed on both the broadleaf and grass components of a pasture to varying degrees (Kain et al. 1979; Barratt et al. 1990; Emberson \& Stephenson 1999).

Six weed groups are considered to be associated with run-out pasture: summer grasses, winter grasses, perennial weeds, summer broadleafs, perennial winter broadleafs and annual winter broadleafs. Summer grasses comprise a complex of genera (e.g. Digitaria sanguinalis, Echinochloa crus-galli, Panicum spp. and Setaria spp.). They are a problem in warm environments as their $\mathrm{C}_{4}$ metabolic pathway operates more efficiently at elevated temperatures. A large summer grass infestation is often the impetus for pasture renovation in the Waikato. Winter grasses such as Poa апnиа are very common over most of New Zealand, and their growth characteristics are very similar to ryegrass. They thrive on cultivated land, have a very fast autumn germination and the soil seed bank generally contains large quantities of their seed.

Perennial weeds include species such as dock (Rumex spp.) and Californian thistle (Cirsium arvense). These weeds are problematic because fragments of their root system have the capacity to develop into individual plants as long as a minimal store of reserves and a shoot and root bud is present in the fragment. Summer broadleaf weeds include willow weed (Persicaria persicaria), fathen (Chenopodium album) and amaranthus species. While these species are only a minor problem in most autumn-sown pastures, the soil seed bank often contains high seed numbers of at least one of these species.

Perennial winter broadleaf weeds include buttercups (Ranunculus spp.) and pennyroyal (Metha pulegium). Buttercups are common in moister environments and are serious pests on dairy farms, where stock refuse to eat them, resulting in a reduction of effective 
grazing area. Annual winter broadleaf weeds include chickweed (Stellaria media) and shepherd's purse (Capsella bursa-pastoris).

The three most damaging nematode genera in New Zealand pastures are root knot (Meloidogyne), cyst (Heterodera) and lesion (Pratylenchus), probably in that order (Yeates et al. 1985; Mercer 1994). The first two cause most damage to the clover component of pasture through reductions in nitrogen fixation and growth. All are virtually ubiquitous on Waikato dairy farms, and almost certainly associated with run-out pasture, so that any succession scheme that is able to reduce the populations of these nematodes will result in greater yields and quality of subsequent pastures.

\section{FORAGE CROPS}

Figure 1 pictorially represents the potential impact of the forage succession, and subsequent succession stages, on the key insect pests associated with the initial succession stage (i.e. run-out pasture).

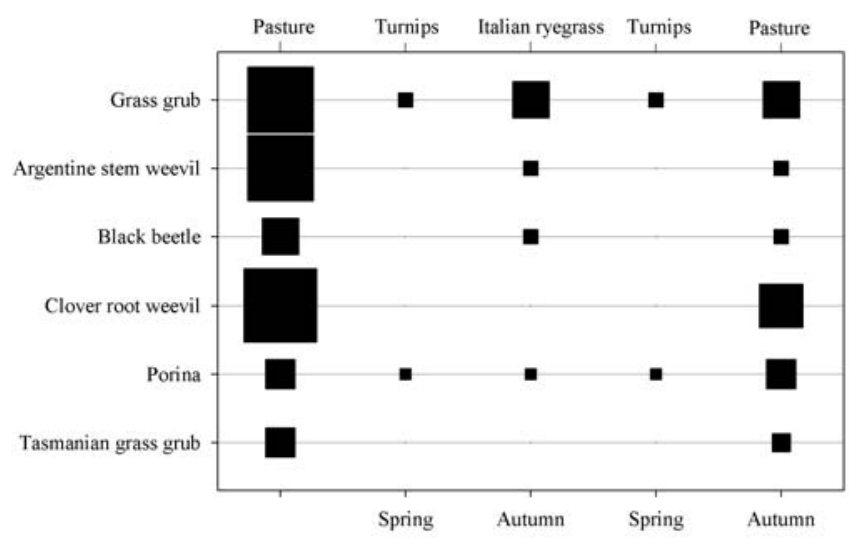

FIGURE 1: Putative impact of a selected forage succession on insect pest populations under a dairying system in the Waikato region. Box size represents relative insect population size at the end of run-out pasture, harvest of the forage crops or one year after sowing of the second pasture. Forage sowing times are given on the basal axis.

In the Waikato dairying situation all six of the pest species could potentially be found in run-out pasture. However, cultivation in preparation for the following turnip crop is likely to significantly reduce larval populations of grass grub, black beetle, porina and Tasmanian grass grub (Stewart 1986; Barratt et al. 1990). During the turnip phase of the rotation the pest potential of Argentine stem weevil and clover root weevil also declines as hosts suitable for these two pests (e.g. Barker et al. 1999; Bell et al. 2004) have been removed. Of these key pests, the main threat to summer turnips comes from larvae of grass grub, which arise from adults dispersing into crops in the October-November period.

Argentine stem weevil and black beetle populations have the potential to increase during the Italian ryegrass phase of the rotation as this crop is a suitable host for these species. However, conditions which allow black beetle populations to increase to densities high enough to cause mass dispersal flights and the weather conditions needed to trigger them rarely occur (Watson 1980). Argentine stem weevil also poses little threat to the short rotation ryegrass as females enter reproductive diapause in early March before egg laying recommences in spring (Goldson 1981; Barker et al. 1988). This largely negates the potential for damage to short rotation Italian ryegrass crops from these two pests. 
The planting of the second turnip crop in the succession, with associated cultivation, would be expected to result in a soil that is relatively free of the insect pest species being considered here.

The expected impact of the forage succession on weeds associated with run-out pasture is illustrated in Figure 2. Summer grasses should not pose much of a problem in turnip crops that are established early in the season as canopy closure will have been achieved by the time temperatures are favourable for summer grass germination and development. Canopy closure can be achieved from either the turnips alone or by turnips with the unwanted assistance of summer broadleaf weeds (T.K. James, unpubl. data). In late established crops, canopy closure may not be achieved in time to suppress summer grasses, offering them an opportunity to get established. The subsequent forage crop of Italian/short rotation ryegrass is more exposed to summer grasses, but only up to the time that temperature drops and especially when frosts eventuate. The situation for the subsequent turnip crop and the establishment of permanent pasture are similar to the first round of turnips and Italian ryegrass, with summer grass problems for the latter gradually occurring when gaps in the canopy start to appear.

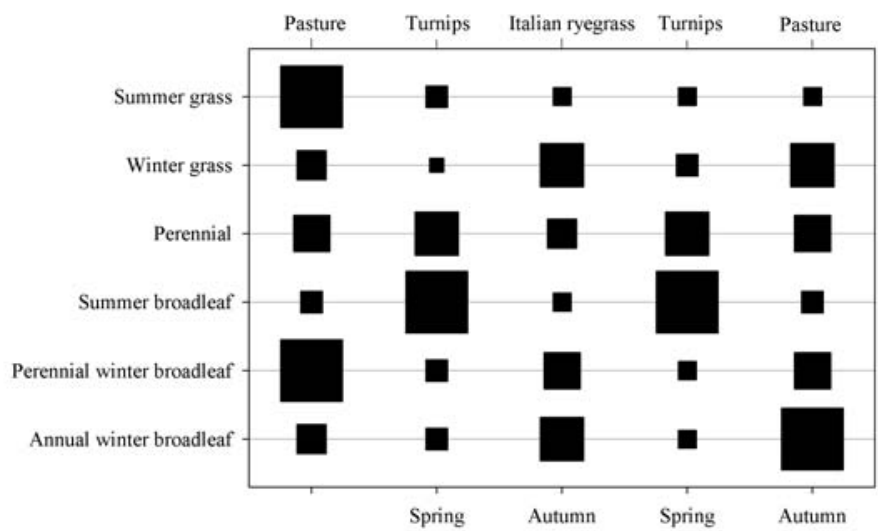

FIGURE 2: Putative impact of a selected forage succession on weed populations under a dairying system in the Waikato region. Box size represents relative weed population size at the end of run-out pasture, harvest of the forage crops or one year after sowing of the second pasture. Forage sowing times are given on the basal axis.

The biggest problems with winter grasses occur in autumn-sown ryegrasses (Vartha 1972), whereas perennial weed problems persist through all stages of the succession. While cultivation may damage the root systems of perennial weeds and reduce the total biomass they contain, it also aids their spread, resulting in an even distribution of perennial weed infestation sources over a field. Cropping successions often provide a good environment for targeting these problem weeds with more efficacious herbicides.

Spring cultivation brings summer broadleaf weed seeds to the soil surface providing them with the conditions required for germination and development. They compete effectively with the relatively widely spaced turnips (Fig. 2) and have the potential to completely over-run them and thereafter boost the number of weed seeds in the soil seed bank.

Summer broadleaf weeds pose a relatively minor problem in the autumn-sown Italian/ short rotation ryegrass, due to a small autumn germination, but pose a bigger problem in the second turnip crop from the fresh population of seed deposited in the soil seed bank 
the previous spring. In the subsequent autumn-sown perennial pasture some problems can be expected at pasture establishment from the summer broadleaf weeds, and those areas with poor pasture cover by spring can experience serious competition from germinating summer broadleaf weeds (T.K. James, unpubl. data).

Perennial winter broadleaf weeds germinate in autumn or well into the winter, which in the Waikato poses problems for the autumn-sown Italian/short rotation ryegrass and also the re-establishing perennial ryegrass swards.

The annual winter broadleaf weeds have the potential to cause major damage to autumn-sown forage crops due to their ability to grow quickly at that time of the year and into the winter. They can germinate throughout the year but germination tends to be more dominant in the autumn. This evaluation indicates that the forage succession has the potential to exacerbate problems with annual winter broadleaf weeds in the newly established permanent pasture (see also Armstrong et al. 2002).

As already mentioned for summer grasses and summer broadleaf weeds, the success of one group of weeds could be influenced by the success of another group of weeds. If canopy closure in turnips is slow and summer broadleaf weeds are controlled with herbicides, there is an opportunity for summer grasses to become dominant and become a serious problem. Similarly, winter grasses, autumn and winter broadleaf weeds and even perennial weeds compete with one another and the sown forage for available resources, space and access to light which are often at a premium. The group that has the ability to get established the fastest (or earliest) has a competitive advantage over the others and in that respect environmental conditions at the time of sowing will dictate which group has the advantage.

The expected impact of the forage succession on nematode populations is illustrated in Figure 3. The forage succession begins with a "typical" plant parasitic nematode burden consisting of the three most damaging genera, which in this case are considered to be represented by the clover ( $M$. trifoliophila) and/or northern (M. hapla) root knot nematodes, clover cyst nematode $(H$. trifolii); and the lesion species, $P$. penetrans and/or $P$. crenatus. The less damaging genera are likely represented by spiral (Helicotylenchus pseudorobustus), pin (Paratylenchus nanus) and stubby root (Paratrichodorus minor) nematodes.

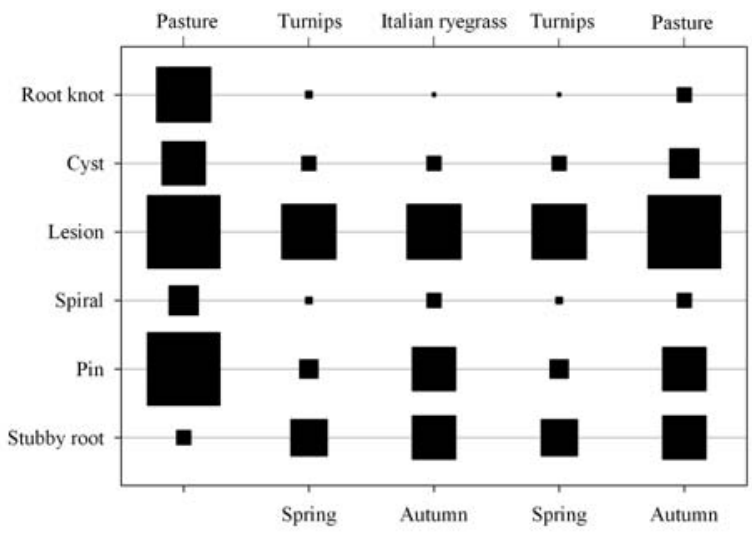

FIGURE 3: Putative impact of a selected forage succession on plant feeding nematode populations under a dairying system in the Waikato region. Box size represents relative nematode population size at the end of run-out pasture, harvest of the forage crops or one year after sowing of the second pasture. Forage sowing times are given on the basal axis. 
Over the course of the illustrated succession, populations of all but lesion (Ogiga \& Estey 1975), pin (Bell \& Watson 2001) and stubby root (Rohde \& Jenkins 1957; Bell $\&$ Watson 2001) nematodes are expected to be reduced to low levels. Although turnips are hosts for stubby root (Rohde \& Jenkins 1957) these nematodes are very patchily distributed within New Zealand (Sturhan et al. 1997) so would likely be a problem on only a few farms where they occur and then probably only if they have light soils.

\section{RE-ESTABLISHED PASTURE}

This analysis indicates that the cropping succession outlined would be expected to reduce populations of grass grub, Argentine stem weevil, black beetle, clover root weevil, porina and Tasmanian grass grub. However, these pests can re-establish rapidly in new pastures (e.g. King \& East 1980; King et al. 1982; Popay 1992; Gerard et al. 1999; Hardwick 2004). This process can be managed to some extent by planting species that are unattractive to pests or contain novel endophytes that confer resistance to pests (e.g. King et al. 1982; Popay et al. 2003; Jensen \& Popay 2004). Additionally, the application of a fungal biocontrol agent to kick start the natural disease cycle (which has likely been disrupted by cultivation) within an emerging population of a pest (e.g. Jackson et al. 1992) or the use of an insecticide at the time of planting can be used. However, although an insecticide can be extremely useful in ensuring that pasture remains pest-free during the period of plant establishment they only delay but not stop the re-infestation process. Furthermore although farmers may use forage rotations to control insect pasture pests there is often little or no thought put into how a rotation may influence weed, plant feeding nematodes and diseases of plants.

From the analysis presented here it appears that the re-establishing pasture, following the succession outlined, is likely to be challenged by re-establishment of perennial weeds, winter grasses and both annual and winter broadleafs. The extent to which any will be a problem will depend on establishment success of the sown species, since any gaps in pasture cover are potential establishment points for weeds (Armstrong et al. 2001). Management of the sowing and grazing of the new pasture is therefore important to the success of the forage succession in reducing weed problems (Seefeldt et al. 2005). It appears that summer grasses, which are likely to be dominant in run-out pasture, are greatly reduced by the forage succession outlined.

It would appear that lesion nematodes would become the dominant nematodes in new pasture established after the succession outlined. These nematodes can attack both grass and clover roots but their impact alone in pasture situations in New Zealand is largely unstudied. Their impact in this situation requires study to fully evaluate the effectiveness of the succession.

Root knot and cyst nematodes are likely to recover only slowly in the first year of the re-establishing pasture, with root knot re-infestation likely coming from infested soil movements into the new pasture (e.g. on stock and machinery). Cyst nematodes are likely to be present in greater abundance than root knot in the new pasture due to their egg-containing cyst stage, which can persist in soil for several years. The build up of root knot and cyst nematodes would be expected to increase markedly in the second and third year in new pasture to reach levels equal to or greater than that in the initial pasture (Watson et al. 2000). Therefore, clover abundance in the re-established pasture, following the forage succession outlined here, is likely to be high for the first one to two years after establishment followed by a decline due to re-invasion of clover root weevil and root knot and cyst nematodes.

A nematode not considered in the succession is the false Columbia root knot (Meloidogyne fallax). This nematode was first reported from New Zealand in 2001 (Marshall et al. 2001) and although considered a pest primarily of potatoes it has a very wide host range (including pasture grasses) and is now widely distributed in New Zealand (Bell et al. 2006). The host range and damage potential of this nematode in New Zealand pastures needs to be addressed. Additionally, some nematodes that are currently considered to have a limited distribution but which are potentially of concern 
in forage successions include cereal cyst (H. avenae, a pest of cereals) (Grandison \& Halliwell 1975) and beet cyst (H. schactii, a pest of turnips and swedes) (Barber 1982). Whether the incidence and impact of these nematodes will increase with increasing forage cropping is unknown.

\section{KNOWLEDGE GAPS}

The patterns of weed and pest population changes depicted here are based on a very specific set of conditions that include intensive soil cultivation between crops, effective weed management and good crop establishment practices, such as the correct fertiliser regime and the use of treated seed at sowing. If farmers change practices (e.g. Wardle \& Yeates 1993), including moving to minimum tillage (e.g. Harris \& Kunelius 1988), the risks associated with pests may alter drastically. These practices require study to maximise their benefit to the farmer and to sustainability.

Only six insect species have been considered here but others may well cause yield loss to various components of the succession, e.g. cabbage white butterfly (Pieris rapae) and springtails (including clover flea Sminthurus viridis) in brassicas. To what extent these insects are a problem in forage successions needs to be quantified.

As well as the competitive interactions already mentioned amongst different weed types, there are interactions between the three pest organism types considered here, and these have not been accounted for in this analysis. For example, dock is a host of cyst nematodes so poor control of this weed could exacerbate nematode problems in the next forage in the succession. Likewise, poor control of broadleaf plantain and docks can exacerbate cutworm (Spodoptera) problems in succeeding crops, and carry-over of Argentine stem weevil problems arise with poor grass control. To what extent these interactions occur for other weed and pest combinations is uncertain and certainly worthy of further study.

Knowledge gaps also exist around the impacts of some of the more recently introduced forage species and cultivars on weeds and pests. Examples include triticale (Triticum x Secale hybrid), persian clover (Trifolium resupinatum), balansa clover (Trifolium balansae), forage oats (Avena sativa) and forage barley (Hordeum vulgare). Even commonly used forages such as maize (Zea mays) have had only limited studies conducted on their impact on pest nematodes. An analysis along the lines carried out in the current paper would identify any potential problems and opportunities with these forages along with knowledge gaps that need to be filled.

It must be recognised that the impacts on insects, weeds and nematodes outlined above are based on both published and unpublished data rather than on empirical evidence so this represents perhaps the biggest knowledge gap. A co-operative effort involving researchers in these and other disciplines is needed to simultaneously determine the actual floral and faunal outcomes of a range of forage successions. In terms of sustainability, management practices, such as minimum tillage (which may reduce impacts of cultivation on soil structure), need investigation to evaluate their impact on pest organisms. Models can be built on such data so that variable pest population starting points can be accommodated and extrapolation to other crops and regions undertaken. Such models may allow for better prediction of likely pests and therefore more targeted application of pesticides, thereby reducing the number and amount needed to be applied. All of these strands can help build towards integrated pest management strategies for forage succession that consider a broad range of both floral and faunal pests.

\section{ACKNOWLEDGEMENTS}

We thank Alison Popay for many insightful comments on an earlier version of the paper and Paul Addison for valuable discussions. 


\section{REFERENCES}

Armstrong ML, Seefeldt SS, Harrington KC 2001. Effect of perennial ryegrass density on ragwort emergence. New Zealand Plant Protection 54: 111-115.

Armstrong ML, Harrington KC, Seefeldt SS 2002. Weed establishment in the second year after high pasture sowing rates. New Zealand Plant Protection 55: 116-120.

Barber CJ 1982. Beet cyst nematode. Biology, damage and control. A new pest problem. In: AgLink FPP95. Ministry of Agriculture and Fisheries, Wellington, New Zealand. $2 \mathrm{pp}$.

Barker GM, Prestidge RA, Pottinger RP 1988. Reproductive phenology of Listronotus bonariensis (Kuschel) (Coleoptera: Curculionidae) in northern New Zealand pastures. Bulletin of Entomological Research 78: 659-668.

Barker GM, Chittranjan-Sinha, Johnston SL 1999. Inter- and intra-population variation in host plant preference in adult stage of Listronotus bonariensis (Kuschel) (Coleoptera: Curculionidae), with evaluation of the contributions of inheritance and habituation. Proceedings of the 7th Australasian Conference on Grassland Invertebrate Ecology. Pp. 246-253.

Barratt BIP, van Toor RF, Ferguson CM, Stewart KM 1990. Grass grub and porina in Otago and Southland: a guide to management and control. Tablet printing company, Dunedin, New Zealand. 104 pp.

Bell NL, Knight KWL, Mercer CF, Shah F, Sturhan D, Aalders LT, Yeates GW, Watson RN, Marshall JW, Page GD 2006. Occurrence and distribution of Meloidogyne spp. nematodes in New Zealand. Society of Nematologists 47th Annual Meeting: in press.

Bell NL, Watson RN 2001. Identification and host range assessment of the nematodes Paratylenchus nanus (Tylenchida: Tylenchulidae) and Paratrichodorus minor (Triplonchida: Trichodoridae). Nematology 3: 483-490.

Bell NL, Addison PJ, Kettlewell FJ, Eden T 2004. The effect of autumn plant host removal on abundance of the clover root weevil (Sitona lepidus) and white clover seedling establishment. Proceedings of the 8th Australasian Conference on Grassland Invertebrate Ecology. Pp. 172-176.

Blank RH 1985. Black beetle or black field cricket - the insect villain of pastures in Northland? Proceedings of the 4th Australasian Conference on Grassland Invertebrate Ecology. Pp. 344-352.

Bluett SJ, Thom ER, Dow BW, Burggraaf VT, Hume DE, Davies E, Tapper BA 2004. Effects of natural reseeding and establishment method on contamination of a novel endophyte-infected perennial ryegrass dairy pasture with other ryegrass/endophyte associations. New Zealand Journal of Agricultural Research 47: 333-344.

Chapman RB 1984. Pasture pests. In: New Zealand Pest and Beneficial Insects. Scott RR ed. Lincoln University, Canterbury, New Zealand. Pp. 119-142.

Clements RO, Murray PJ 1991. Incidence and severity of pest damage to white clover. Aspects of Applied Biology 27: 369-371.

East R, King PD, Watson RN 1981. Population studies of grass grub (Costelytra zealandica) and black beetle (Heteronychus arator) (Coleoptera: Scarabaeidae) New Zealand Journal of Ecology 4: 56-64.

Eerens JPJ, Hardwick S, Gerard PJ, Willoughby BE 2005. Clover root weevil (Sitona lepidus) in New Zealand: the story so far. Proceedings of the 67th New Zealand Grassland Association: 19-22.

Emberson RM, Stephenson BP 1999. The development, feeding behaviour and activity of larvae of Tasmanian grass grub, Acrossidius tasmaniae (Hope), in Canterbury, New Zealand. Proceedings of the 7th Australasian Conference on Grassland Invertebrate Ecology. Pp. 27-34. 
Gerard PJ, Addison PJ, Hardwick S, Willoughby BE 1999. Establishment of the invader: Insights into the life history and biology of Sitona lepidus in the Waikato region of New Zealand. Proceedings of the 7th Australasian Conference on Grassland Invertebrate Ecology. Pp. 35-51.

Goldson SL 1981. Reproductive diapause in the Argentine stem weevil, Listronotus bonariensis (Kuschel) (Coleoptera: Curculionidae), in New Zealand. Bulletin of Entomological Research 71: 275-287.

Goldson SL, Rowarth JS, Caradus JR 2005. The impact of invasive invertebrate pests in pastoral agriculture: a review. New Zealand Journal of Agricultural Research 48: 401-415.

Goold GJ, Weeda WC 1985. The value of regrassing with improved pasture cultivars in Waikato. Proceedings of the New Zealand Grassland Association 46: 179-183.

Grandison GS, Halliwell HG 1975. A new pest of cereals. New Zealand Journal of Agriculture 130: 64-65.

Harris W, Kunelius HT 1988. Production of pastures in the second year after drilling of red clover and ryegrass. New Zealand Journal of Experimental Agriculture 16: $17-20$.

Hardwick S 2004. Colonisation of renovated pastures in Waikato by four coleopteran species. New Zealand Plant Protection 58: 304-309.

Jackson TA, Pearson JF, O'Callaghan M, Mahanty HK, Willocks M 1992. Pathogen to product-development of Serratia entomophila (Enterobacteriaceae) as a commercial biological control agent for the New Zealand grass grub (Costelytra zealandica). In: Jackson TA, Glare TR ed. Use of pathogens in scarab pest management. Intercept, Andover, UK. Pp. 191-198.

Jensen JG, Popay AJ 2004. Perennial ryegrass infected with AR37 endophyte reduces survival of porina larvae. New Zealand Plant Protection 57:323-328.

Kain WM, Slay MW, Atkinson DS 1979. Evaluation of grass grub-plant interactions of grasses sown with and without white clover in the central Hawke's Bay. Proceedings of the 32nd New Zealand Weed and Pest Control Conference: 86-91.

King PD, East R 1980. Effects of pasture composition on the dynamics of Heteronychus arator and Graphognathus leucoloma populations. Proceedings of the 2nd Australasian Conference on Grassland Invertebrate Ecology. Pp. 79-82.

King PD, Meekings JS, Mercer CF 1982. Effects of whitefringed weevil (Graphognathus leucoloma) and black beetle (Heteronychus arator) populations on pasture species. New Zealand Journal Agricultural Research 25: 405-414.

Marshall JW, Zijlstra C, Knight K 2001. First record of Meloidogyne fallax in New Zealand. Australasian Plant Pathology 30: 283-284.

Mercer CF 1994. Plant-parasitic nematodes in New Zealand. New Zealand Journal of Zoology 21: 57-65.

Ogiga IR, Estey RH 1975. Penetration and colonization of Brassica rapa and Zea mays root tissues by Pratylenchus penetrans. Phytoprotection 56: 23-30.

Popay AJ 1992. Population regulation of Costelytra zealandica by pathogens in the North Island of New Zealand. In: Jackson TA, Glare TR ed. Use of pathogens in scarab pest management. Intercept, Andover, UK. Pp. 141-151.

Popay AJ, Hume DE, Davis KL, Tapper BA 2003. Interactions between endophyte (Neotyphodium spp.) and ploidy in hybrid and perennial ryegrass cultivars and their effects on Argentine stem weevil (Listronotus bonariensis). New Zealand Journal of Agricultural Research 46: 311-319.

Rohde RA, Jenkins WR 1957. Host range of a species of Trichodorus and its host-parasite relationships on tomato. Phytopathology 47: 295-298.

Seefeldt SS, Stephens JMC, Verkaaik ML, Rahman A 2005. Quantifying the impact of a weed in a perennial ryegrass-white clover pasture. Weed Science 53: 113-120.

Stewart KM 1986. Control of grass grub (Costelytra zealandica) by cultivation in spring 
and summer. New Zealand Journal of Experimental Agriculture 14: 83-87.

Sturhan D, Wouts WM, Grandison GS, Barber CJ 1997. Nematode vectors of plant viruses in New Zealand. New Zealand Journal of Zoology 24: 309-322.

Vartha EW 1972. Effect of Poa trivialis L. on growth of perennial ryegrass and white clover. New Zealand Journal of Agricultural Research 15: 620-628.

Wardle DA, Yeates GW 1993. The dual importance of competition and predation as regulatory forces in terrestrial ecosystems: evidence from decomposer food-webs. Oecologia 93: 303-306.

Wardle DA, Nicholson KS, Ahmed M, Rahman A 1995. Influence of pasture forage species on seedling emergence, growth and development of Carduus nutans. Journal of Applied Ecology 32: 225-233.

Watson RN 1980. Dispersal and distribution of Heteronychus arator in New Zealand (Coleoptera: Scarabaeidae). Proceedings of the 2nd Australasian Conference on Grassland Invertebrate Ecology. Pp. 149-152.

Watson RN, Bell NL, Neville FJ, Davis LT 2000. Pest populations during the first six years in ryegrass pastures containing white or Caucasian clover. New Zealand Plant Protection 53: 410-414.

Yeates GW, Watson RN, Steele KW 1985. Complementary distribution of Meloidogyne, Heterodera and Pratylenchus (Nematoda: Tylenchida) in roots of white clover. In: Chapman RB ed. Proceedings of the Fourth Australasian Conference on Grassland Invertebrate Ecology. Pp. 71-79. 